\title{
Research Advances on Tall Fescue Salt Tolerance: From Root Signaling to Molecular and Metabolic Adjustment
}

\author{
Erick Amombo, Huiying Li, and Jinmin Fu' \\ Key Laboratory of Plant Germplasm Enhancement and Specialty Agriculture, Wuhan Botanical \\ Garden, Chinese Academy of Sciences, Wuhan, Hubei 430074, People's Republic of China; \\ and University of Chinese Academy of Sciences, 19 Yuquan Road, Beijing 100049, \\ People's Republic of China
}

\begin{abstract}
AdDitional INDEX wORDs. transcriptional factors, phytohormones, endophyte, sugars, nonhormonal, endophyte, Festuca arundinacea

Abstract. Soil salinity is one of the major abiotic stress factors that constrain plant growth and limit crop productivity. About a quarter of the global land area is affected by salinity; therefore, there is increased need to develop salt-tolerant crops. Tall fescue (Festuca arundinacea) is one of the most important cool-season turfgrasses, which has medium tolerance to salinity and has a promising potential to be used as a turfgrass under saline conditions. However, up to now, the maximum use of tall fescue under salinity stress is still limited by inadequate scientific literature. Recent studies have attempted to identify various adaptive responses to salinity stress at molecular, cellular, metabolic, and physiological levels in tall fescue. The successful integration of information concerning signal sensing, molecular tools with recent advances in -omics would certainly provide a clue for creating salt-tolerant tall fescue. Because salinity limits water availability to plants via hindering water absorption, and by inducing physiological drought, here we review and propose a probable mechanism of tall fescue response to salinity stress and to similar effects induced by drought based on published literature.
\end{abstract}

Soil salinity is a critical environmental problem that affects about one-third of the world's irrigated agricultural land and is a major constraint on agricultural productivity (Allakhverdiev et al., 2000; Cheeseman, 1988). Despite being one of the most important cool-season turfgrasses, the use of tall fescue in tropical regions has been constrained by remarkably poor salt tolerance compared with warm-season turfgrasses (Alshammary et al., 2004; Watkins et al., 2011). Interestingly, there are remarkably great intraspecies cultivar variations in tall fescue water stress tolerance (Carrow, 1996). The decisive factor in the intraspecific variations has been attributed to differences in morphological characteristics especially the roots (Beard, 1989; Huang and Fry, 1998; Marcum et al., 1995; Youngner et al., 1981). Generally, the salt-tolerant cultivars usually develop longer and extensive roots compared with salt-sensitive cultivars (Fig. 1). Because roots play integral roles in nutrient uptake in tall fescue, any unfavorable soil conditions such as elevated salinity would adversely affect growth (Dean et al., 1996). Salinity and drought-triggered water deficit have been one of the major causes of root death of tall fescue; hence, to enhance salt adaptation, persistent tall fescue root growth is a prerequisite (Weaver and Zink, 1955). Understanding the mechanisms of tall fescue salt tolerance will uncover new information that can be incorporated into breeding programs to improve salinity tolerance.

\section{Response of Tall Fescue Roots to Salinity}

Water absorption efficiency by plant roots is a vital determinant of salinity resistance, and water absorption relies on Received for publication 29 Mar. 2017. Accepted for publication 31 May 2017.
${ }^{1}$ Corresponding author. E-mail: ju@@wbgcas.cn. the root size and its spatial distribution (Gupta and Huang, 2014). Recently, many studies on roots have focused on the morphological and growth characteristics, whereas extensive rooting has been positively correlated with increased resistance to water deficiency (Hays et al., 1991; Taylor, 1983). Tall fescue roots are closely associated with the surrounding soil and develop highly intricate branching that enables them to explore their environment (Bennett and Doss, 1960; Beyrouty et al., 1990; Bonos et al., 2004; Hu et al., 2015; Newman and Moser, 1988). Like other plants, the detrimental effects of salinity on tall fescue can be attributed to ion toxicity, and osmotic and nutrient imbalances (Bowman et al., 2006). The $\mathrm{NaCl}$-induced toxicity, ionic imbalances, and water deficiency in plants result from the osmotic stress caused by excess $\mathrm{Na}^{+}$levels in the surrounding soil and a gross disruptions in the cytosolic $\mathrm{Ca}^{2+}$ as well as $\mathrm{K}^{+}$homeostasis (Apel and Hirt, 2004; Gorham et al., 1990; Hu et al., 2011; Lynch et al., 1989; Munns, 1988, 1993, 2011; Munns and Tester, 2008; Schachtman et al., 1991). Putatively, each of the limiting factors can be sensed by an elaborate system of stress sensors and then translated into a broad array of physiological and genetic changes that optimize plant performance under saline conditions. Moreover, it is highly probable that the salt-stress response pathways may function simultaneously (Bray, 1997). Thus, the prevention of salt-induced root desiccation and subsequent detriments is one of the mechanisms to ameliorate the adverse effects of salt (Fu et al., 2004).

\section{Salt-Stress Signaling and Transcriptional Regulation}

When plants are exposed to environmental stress, their signaling pathways undergo a complex and interlinked network of processes which triggers response. Plants specificity to stress 


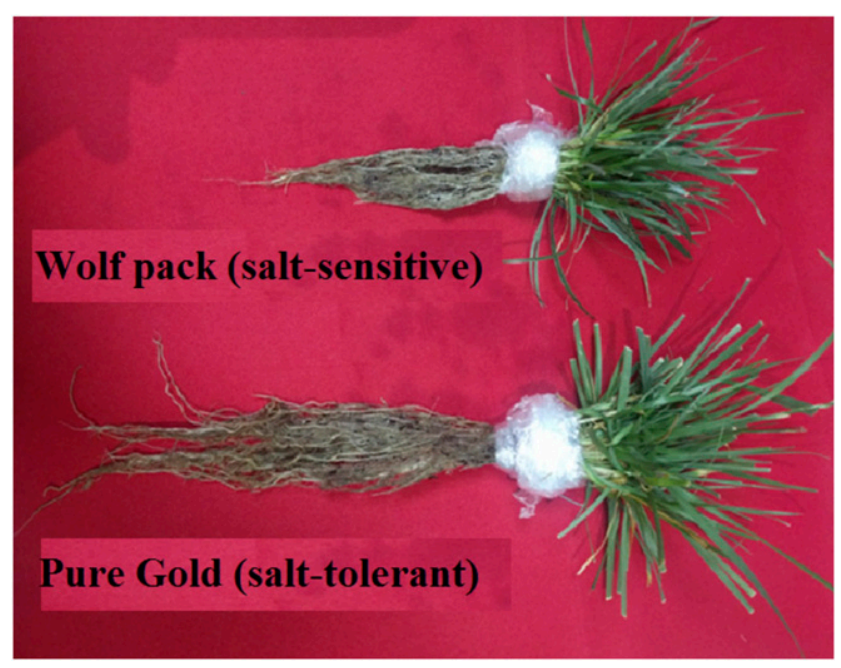

Fig. 1. Differences in root sizes of salt-tolerant 'Pure Gold' and sensitive 'Wolf Pack' tall fescue accession collected from U.S. Department of Agriculture. The plants were cultivated in Wuhan Botanical Garden, Chinese Academy of Sciences and evaluated for salinity tolerance.

signals makes it easy to figure out their specific signal sensor (Boudsocq et al., 2010; Dinneny et al., 2008; Dubiella et al., 2013). Currently, only a few salt-stress sensors have been identified, and there is a scarcity of evidence to confirm the presence of a crosstalk between the sensors in tall fescue. Tall fescue has a medium salt tolerance, and its yield is decreased $50 \%$ at an electrical conductivity of $12 \mathrm{dS} \cdot \mathrm{m}^{-1}$ (Richards, 1954); therefore, a complete rearrangement of cellular homeostasis via multiple pathways is a prerequisite for their acclimation to elevated environmental salinity. Recently, phytohormones, secondary messengers, and protein kinases cascades, which are vital components within the salt-stressinduced signaling network, have been reported to regulate a multitude of biochemical and physiological processes in plants under salinity stress (Hirayama and Shinozaki, 2010). In particular, the regulation of gene expression under salinity stress is entirely dependent on the signals.

\section{Nonhormonal signaling}

As sessile organisms, tall fescue perceives environmental cues such as salinity via changing its morphologies. The initial step of salt response in plants is hormonal or nonhormonal signaling (Knight, 2000). In this section, the nonhormonal mechanisms of salt-stress-signaling systems that trigger tall fescue response to salinity are discussed. These signals are first sensed by elaborate receptors and transmitted to the nucleus by a complex network.

$\mathbf{C A}^{2+}$ Signaling. Apart from being one of the essential nutrients, $\mathrm{Ca}^{2+}$ also acts as a secondary messenger which mediates response to salt stress (Blumwald, 1987; Cabot et al., 2009; Dodd et al., 2010; Harper et al., 2004; Kanchiswamy et al., 2010; Sheen, 1996; Srivastava et al., 2013). Intracellularly, $\mathrm{Ca}^{2+}$ serves as a secondary messenger during abiotic stress signaling (Chidananda et al., 2010; Sanders et al., 2002). The $\mathrm{Ca}^{2+}$ signaling channels have been associated with salt-stress-induced cytosolic $\mathrm{Ca}^{2+}$ elevations (DeWald et al., 2001; Takahashi et al., 2001). Studies have reported that exogenous application of $\mathrm{Ca}^{2+}$ alleviated salt stress in tall fescue seedlings (Maeda and Nakazawa, 2008). In separate studies, it was observed that the exogenous addition of $\mathrm{Ca}^{2+}$ to the growth medium ameliorated salt stress in various plants (El-Hamdaoui et al., 2003; Lahaya and Epstein, 1969; Sotiropoulos, 2007). Recently, $\mathrm{Hu}$ et al. (2016a) investigated the interplay between $\mathrm{Ca}^{2+}$ and hydrogen peroxide $\left(\mathrm{H}_{2} \mathrm{O}_{2}\right)$ signaling in salt-stressed perennial ryegrass (Lolium perenne), which is a close relative of tall fescue. They observed that $\mathrm{Ca}^{2+}$ signaling remarkably enhanced the physiological response to salty conditions. The $\mathrm{Ca}^{2+}$ signaling pathway maintained high levels of reactive oxygen species (ROS) homeostasis in the stressed grass by increasing the responses of antioxidant genes, proteins, and enzymes. Studies have reported that exogenous application of $\mathrm{Ca}^{2+}$ alleviated salt stress in tall fescue seedlings (Maeda and Nakazawa, 2008). Xu et al. (2016) observed that $\mathrm{Ca}^{2+}$ induced antioxidant enzymes activity in tall fescue under oxidative stress. The effects of $\mathrm{Ca}^{2+}$ application were connected with the decrease in the $\mathrm{Na}^{+}$content in the plant roots and shoots and increased ATPase activity in tall fescue roots. In addition, tall fescue shoot selectively took $\mathrm{Ca}^{2+}$ under salinity stress (Gao et al., 2012). These results agree with those of Lunt et al. (1961) and Torello and Symington (1984) on tall fescue and of Kinraide (1999) on rice (Oryza sativa). It was also reported that the alleviatory effects of $\mathrm{Ca}^{2+}$ on salt stress in tall fescue might be caused by a reduction in the $\mathrm{Na}^{+}$intake and transfer from roots to the shoots (Cramer et al., 1989). Thus, understanding the $\mathrm{Ca}^{2+}$ signaling and the subsequent calciumdependent events would be essential for improving tall fescue productivity under salinity stress.

Potential Crosstalk between $\mathrm{CA}^{2+}$ and Salt overly SEnsitive (SOS) PAThways. Along $\mathrm{Ca}^{2+}$, the SOS signaltransduction pathway may play a key role in the ionic homeostasis and salt tolerance in plants (Batelli et al., 2007; Ji et al., 2013; Yang et al., 2009; Yue et al., 2012). Ma et al. (2014) reported that the overexpression of arabidopsis (Arabidopsis thaliana) $S O S 1+S O S 2+S O S 3$ genes enhanced salt tolerance in tall fescue. In their study, they observed that $S O S 1+S O S 2+$ $S O S 3$ overexpressing tall fescue plants exhibited high growth rates and accumulated less $\mathrm{Na}^{+}$and more $\mathrm{K}^{+}$in the roots after $\mathrm{NaCl}$ treatment. The $\mathrm{Ca}^{2+}$ influx was higher in the transgenic plants than in the wild-type regimes, and the SOS overexpressors exhibited higher antioxidant enzyme activities suggesting increased ROS scavenging capacity. Recent studies have attempted to uncover the link between SOS and $\mathrm{Ca}^{2+}$ signaling pathways in plants under salinity stress. Interestingly, it was found that SOS3 is actually a $\mathrm{Ca}^{2+}$ sensor, which transduces the signal downstream after activating and interacting with the SOS2 protein kinase. The SOS3-SOS2 complex was found to restore cellular ion homeostasis in tall fescue (Mahajan et al., 2008). Verslues (2007) observed that the interaction between SOS2 and protein kinases enhanced the $\mathrm{H}_{2} \mathrm{O}_{2}$ signaling and led to water stress tolerance in arabidopsis. Collectively, these results show that there might be a complex crosstalk between the SOS and $\mathrm{Ca}^{2+}$ in tall fescue during the salt-stress response. In a closely related species, $\mathrm{Hu}$ et al. (2016a) observed that $\mathrm{H}_{2} \mathrm{O}_{2}$ signaling could activate ROS homeostasis by inducing antioxidant genes via the $\mathrm{Ca}^{2+}$ signaling pathway in perennial ryegrass leaves. Having described the role of the SOS3-SOS2 complex, it would be important to find out the contribution of SOS1 in salt tolerance of tall fescue. The SOS1 genes encode a plasma membrane $\mathrm{Na}^{+} / \mathrm{H}^{+}$exchanger (antiporter), and during salt stress, the upregulation of SOS1 transcript level was diminished in the $\operatorname{sos} 3$ and $\operatorname{sos} 2$ mutant plants (Shi et al., 2000). This suggests that 
SOS3-SOS2 kinase complex may control both the expression and activity of SOS1. High SOS1-encoded $\mathrm{Na}^{+} / \mathrm{H}^{+}$antiporter activity in tonoplast vesicles was observed in tall fescue as a result of overexpression of the $A t N H X 1$ gene, and it enhanced salt tolerance to the transformed tall fescue progenies (Zhao et al., 2007). In addition, tall fescue plants that overexpressed AtNHXI gene were more resistant to salinity stress. The results suggest that this accumulation of $\mathrm{Na}^{+}$in the vacuoles of root cells, mediated by vacuolar $\mathrm{Na}^{+} / \mathrm{H}^{+}$antiporters, might reduce the toxic effects of salinity to tall fescue and thus enhance its salt tolerance.

Protein kinases. Recently, many expressed sequence tags of the known stress response genes have been identified from stressed tall fescue tissue libraries, and most of the identified tags represented genes that code for antioxidant proteins as well as various transcription factor protein families (Li et al., 2017; Mian et al., 2008). In addition, through de novo assembly and characterization of tall fescue transcriptome under water stress, some important revelations about the gene regulatory mechanism of water stress responses in tall fescue have been unraveled. In particular, after osmotic stress treatment, many sequence contigs have been annotated to signaling and water stress-related gene functions. Interestingly, protein kinases have constituted the highest group among the molecular function ontology (Talukder et al., 2015). This suggests that protein kinases and their complexes might play a crucial role in signal sensing and transduction in tall fescue during physiological drought caused by salinity stress. Several mitogenactivated protein kinases (MAPKs) were activated by cold, salt, and drought in monocot and dicot plants (Ichimura et al., 2000; Jonak et al., 1996; Kiegerl et al., 2000), and genetic manipulation of MAPK signaling altered plant tolerance to abiotic stresses (Blanco et al., 2006; Lzwiy and Morris, 2007; Shou et al., 2004; Xiong and Yang, 2003). For example, Festuca arundinacea zinc finger $(F a Z n F)$ is an MAPK gene, which encodes a zinc finger $(\mathrm{ZnF})$ protein that was identified during salt-stress analysis in tall fescue. A $F a Z n F$ gene was upregulated in response to osmotic stress suggesting they may play a key role in enhancing salt-induced drought tolerance. The genes were upregulated in the calli overexpressing $\mathrm{FaZnF}$ genes when compared with control cell lines. In detail, FaZnF is a $\mathrm{ZnF}$ protein that is involved in the regulation of pathways initiated by the salt-stress response (Martin et al., 2012), which might influence the transcription of oxidative stress pathway genes in tall fescue. Apart from salt-related genes, recent studies have revealed the positive role for the MAPK-based signaling pathway in salt stress-induced proline accumulation (Kong et al., 2011; Zhang et al., 2011). The capacity to accumulate proline has been correlated with stress tolerance (Barnett and Naylor, 1966; Hasegawa et al., 2000; Kiyosue et al., 1996; Stewart and Lee, 1974; Vendruscolo et al., 2007). Proline acts as a vital osmolyte, an ROS scavenger, and as a molecular chaperone, which stabilizes the structure of proteins, thus protecting cells from stress-induced damage (Hare and Cress, 1997; Szabados and Savoure, 2010; Verbruggen and Hermans, 2008; Voetberg and Sharp, 1991). Proline accumulates in many plant species in response to different environmental stresses including high salinity (Rhodes et al., 1986). Man et al. (2011) investigated the osmotic stress tolerance associated with proline in two tall fescue genotypes. The major differences between the two tall fescue genotypes were related to the higher proline accumulation in the water stress-tolerant accession compared with the sensitive counterpart. Collectively, high proline content lowered the osmotic potential and helped to maintain cell turgor, which enabled cell enlargement and excellent tall fescue growth during water stress. Alves and Setter (2004) had previously confirmed that proline and some phytohormones jointly allowed $\mathrm{CO}_{2}$ assimilation by partially opening stomata, and served as a free radical scavenger which suppressed free radical-mediated damage during osmotic stress in tall fescue.

\section{Hormonal signaling}

Phytohormones act as crucial molecules that perceive and relay stress signals to downstream molecules to trigger transduction pathways in tall fescue under salt stress. Thus, to understand clearly the roles of different plant hormones in saltstress tolerance in tall fescue, a clear and practical link should be achieved.

ABscisic ACID (ABA). Abscisic acid plays a vital role in the response of plants to salinity, and $\mathrm{ABA}$-deficient plant mutants performed poorly under salinity stress (Xiong and Zhu, 2003; Xiong et al., 2001). In arabidopsis, exogenously applied ABA induced a number of genes that responded to osmotic stress (Kazuo and Yamaguchi-Shinozaki, 2007; Zhu, 2002). In response to salt stress, small molecules such as $\mathrm{ABA}$ and $\mathrm{Ca}^{2+}$ are used by plants to induce various signaling cascades (Pei, 2000). Salt-stress signaling via $\mathrm{Ca}^{2+}$ and $\mathrm{ABA}$ mediated the expression of the dehydration-responsive element (DRE). The DRE was identified as an ABA-independent cis-acting element, which was vital for the regulation of gene expression in response to high salinity in arabidopsis (Yamaguchi-Shinozaki and Shinozaki, 2005). Subsequently, DRE was identified in many promoters of salt-stress-inducible genes in tall fescue, and DRE overexpressor lines exhibited tolerance to salinity. Previously, DRE was overexpressed in tall fescue and other plants (Dubouzet et al., 2003; Ito et al., 2006; Oh et al., 2005; Pellegrineschi et al., 2004). The transgenic plants showed tolerance not only to drought and cold but also to high salinity. Transgenic tall fescue, which contained DRE genes, accumulated a significantly higher level of antioxidant enzymes and proteins under osmotic stress conditions than control plants (Zhao et al., 2007). These data suggest that the DRE regulon exists in tall fescue and can be used to improve tolerance to high salinity via gene transfer. Previous metabolic studies in tall fescue focused on ABA-mediated stomatal closure. Gao and Li (2014) reported that salt-tolerant tall fescue exhibited slower ABA accumulation rate than sensitive cultivars during short-term salt stress. This may suggest that low accumulation rate of ABA in tall fescue leaves could be beneficial for the maintenance of photosynthesis during a salt-induced physiological drought in tall fescue. Apart from being an integral regulator of abiotic stress signaling, ABA also may promote stomatal closure to reduce water loss by transpiration, induce the expression of numerous stress-related genes and initiate stress-induced metabolic adjustments (Cutler et al., 2010; Raghavendra et al., 2010; Umezawa et al., 2010).

Cytokinins AND INDOLe-3-ACETIC ACID (IAA). Cytokinins delay plant senescence process by maintaining the integrity of the tonoplast membrane (Thimann, 1987). Plants with higher cytokinins exhibit greater osmotic stress tolerance and exogenously applied cytokinins could improve tall fescue tolerance to water stress (Zhang and Schmidt, 2000; Zhang et al., 2005). Indole-3-acetic acid is associated with root initiation and growth (Nordstrom et al., 1991). A recent study has shown that leaf tissue IAA content was positively correlated with 

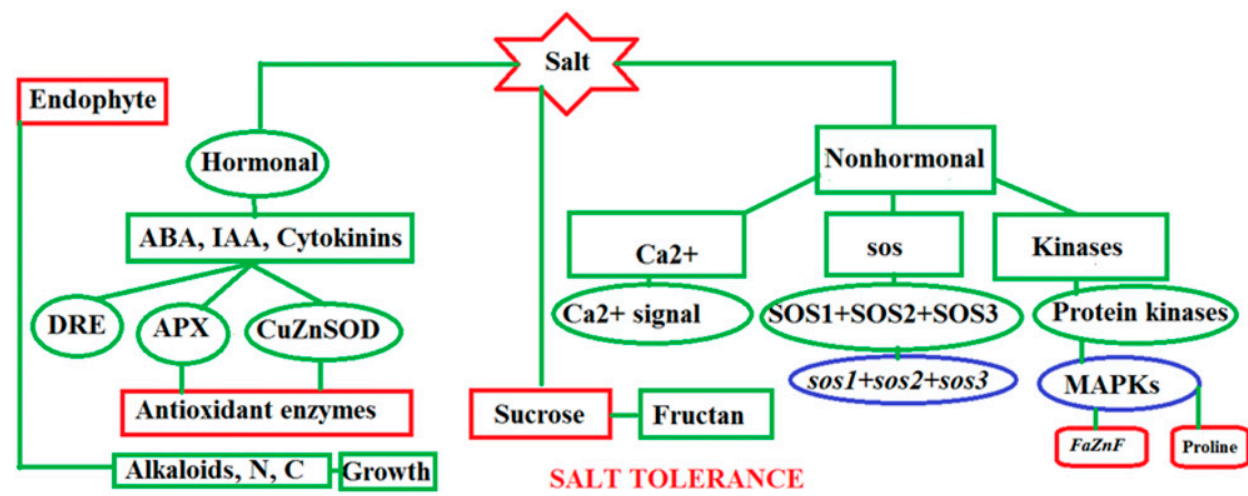

Fig. 2. Proposed mechanism of salinity tolerance in tall fescue. Salt-stress activates changes in the production of abscicic acid (ABA), indole-3-acetic acid (IAA), and cytokinins by tall fescue roots. The signal is transduced leading to the expression of genes that are responsible for biosynthesis superoxide dismutases (SOD) and ascorbate peroxidase (APX) enzymes to scavenge excess reactive oxygen species (ROS) and drought responsive elements (DRE). The nonhormonal response involves activation of the $\mathrm{Ca}^{2+}$ pathway to maintain ionic homeostasis and biosynthesis of osmolytes (such as sucrose and fructans), which decreases the osmotic potential of cells thus facilitating water intake. In addition, tall fescue-endophyte symbiosis also provides crucial metabolites (such as alkaloids and organic carbon) which play important role in osmotic adjustment thus enhancing salt tolerance; $\mathrm{SOS}=$ salt overly sensitive, $\mathrm{FaZnF}=$ Festuca arundinacea zinc finger protein, MAPKs $=$ mitogen-activated protein kinases.

drought tolerance, and exogenous application of indole-3butyric acid increased endogenous IAA, which improved osmotic stress tolerance in tall fescue (Zhang et al., 2009). Osmotic stress reduced turfgrass quality, relative leaf water content, leaf IAA and cytokinin content, and increased proline content. Taken together, these findings show that the metabolism of ABA, cytokinins, and IAA might be associated with salinity tolerance in tall fescue. Selection of cultivars that are sensitive to exogenous application of phytohormones under salt stress may be a practical approach to improving tall fescue salinity tolerance.

\section{Metabolism and Osmotic Adjustment}

Osmotic adjustment is one of the most important strategies adopted by many plants to help them overcome salt stress (Bernstein, 1961, 1963). Kirkham et al. (1969) observed that highly salt-tolerant barley (Hordeum vulgare) had lower osmotic potential than salt-sensitive green bean (Phaseolus vulgaris). West et al. (1990) reported that young tall fescue plants exhibited high resistance to water deficit due to a remarkable decline in water potential and turgor. Metabolitedriven osmotic adjustment is vital for plants response to osmotic stress to ensure their proper growth and development. Elucidation of the metabolism of various compounds and how they are controlled at the transcriptional level in tall fescue would contribute to our understanding of salt tolerance and provide tools to improve crops. Because of their crucial roles in plant growth under environmental stress, the metabolism of several compounds has been studied in tall fescue under salinity stress.

Sucrose. Sucrose serves as a crucial osmotic solute in plants under salt and drought stress (Fu et al., 2007; Premachandra et al., 1992; Rekika et al., 1998). The effect of water deficits on sucrose levels has been reported in some plants. For example, improved response of a bean ( $P$. vulgaris) to osmotic stress was associated with sucrose metabolism (Castrillo, 1992; Vassey et al., 1991). Zhang and McManus (2000) reported an increased sucrose level in white clover (Trifolium repens) growing under osmotic stress. Fu et al. (2010) observed that tall fescue that was exposed to a short-term osmotic stress accumulated higher sucrose content than well-irrigated controls, which enabled water intake. Higher sucrose levels in water-stressed tall fescue might contribute to improved salt-induced osmotic stress by decreasing the osmotic potential of the roots.

Fructan. Fructan is a metabolite that is synthesized directly from sucrose as the sole precursor and consists of polymeric chains of fructose (Pavis et al., 2001). Temperate grasses such as tall fescue accumulate water-soluble fructans. The biosynthesis and accumulation of fructans showed remarkable seasonal variation (Pollock and Jones, 1979), and their mobilization played an important role in tall fescue regrowth and defoliation (Morvan-Bertrand et al., 2001). However, it is unclear how fructan metabolism is actively involved in tall fescue salinity tolerance. Fructan content was reported to increase with osmotic stress as sucrose concentration increased in tall fescue. This might be attributed to the fact that sucrose is the substrate for fructan synthesis (Schnyder and Nelson, 1987). Later, Spollen and Nelson (1994) analyzed the behavior of fructan to salt stress in tall fescue. The main outcome of that study was that fructan metabolism was involved in osmotic-stress tolerance and shoot growth via lowering cellular osmotic potential which might confer higher salinity tolerance.

Reactive Oxygen SPECIES. Reactive oxygen species are produced in both stressed and unstressed plants cells. Plants have well-developed defense systems against ROS which involves both limiting its formation as well as instituting its removal (Huang, 2001; Munns, 2002). In particular, plants respond to high ROS via increased enzymatic and nonenzymatic antioxidant processes (Alscher and Hess, 1993), but the precise mechanism underlying the process in tall fescue is still not understood. Many studies have revealed high accumulation of antioxidant enzymes in tall fescue under lead (Lou et al., 2017), aluminium (Jin et al., 2011), heat (Du et al., 2009; Hu et al., 2015, 2016b; Jiang et al., 2001). Bi et al. (2016) investigated the behavior of antioxidant compounds in tall fescue during induced water stress. They observed a high production of superoxide dismutases (SOD), peroxidases (APX), and catalases. At the same time, a decline in the level of malonaldehyde in osmotic tolerant tall fescue compared with osmotic-sensitive counterpart was observed. At the gene level, Lee et al. (2007) observed that simultaneous overexpression of both CuZnSOD and APX in transgenic tall fescue plants conferred an increased tolerance to a wide range of abiotic stresses including salinity. This was supported later by the observation that the genes encoding copper-zinc SOD (CuZnSOD) and APX enzymes were overexpressed under salt stress which decreased ROS and subsequently improved salt tolerance of tall fescue (Kravchik and Bernstein, 2013). 


\section{Symbiotic Metabolite Sharing}

A symbiotic association that is specific to tall fescue is the infection with the Neotyphodium and Epichloe fungal species, which may provide tall fescue with the beneficial metabolites (Christensen and Voisey, 2009; Clay and Schardl, 2002; Leuchtmann et al., 2000). Recently, Hosseini et al. (2015) reported that tall fescue-endophyte association profoundly increased crucial plant metabolites in the soil especially carbohydrates. The specific mechanisms of endophyte-enhanced salt-stress avoidance or tolerance in tall fescue are still complex and might involve direct and indirect effects of the fungal metabolites on the host plant. Elmi and West (1995) reported that infection of tall fescue with endophyte influenced the osmotic adjustment and water-deficit recovery of tall fescue. Metabolomic responses to osmotic stresses are usually linked to changes in the availability of essential nutrients (Nagabhyru et al., 2013). Recently, it was reported that endophytes might actually produce growth regulators in tall fescue (Debattista et al., 1990). Recent advances in analytical chemistry, such as mass spectrometry-based methods, have allowed botanists to explore metabolomic profiles of tall fescue under environmental stresses such as salinity (Balmer et al., 2013). Metabolomics analyses which compared endophyte-infected with uninfected tall fescue plants showed a significant decrease in the nitrogenous compounds, and some fiber components with a profound increase in simple sugars and organic acids (Bush et al., 1997; Rasmussen et al., 2008). In addition, tall fescue biomass and phenolic and organic carbon contents were influenced by endophyte status of tall fescue cultivar and their interaction (Guo et al., 2015). Achevaleta et al. (1989) observed an increased $\mathrm{N}$ level in endophyte-infected plants compared with noninfected plants and higher tolerance to osmotic stress. When tall fescue was grown in saline soils, the endophyte infection also significantly increased the tiller number, shoot height, and the total biomass of the host grass (Yin et al., 2014). The results indicate that there are positive benefits derived from the endophyte-tall fescue association which resulted in growth stimulation, improved survival, and osmotic stress tolerance to the host plant. Apparently, this association could be vital for salinity tolerance enhancement in tall fescue. However, the enhanced salt tolerance in tall fescue via endophyte modification is not reliable and universally expressed, moreover, tall fescue responses to endophytes involve complex adjustments, which are poorly understood. In addition, because alkaloids produced by many endophytes cause severe animal health hazards, the focus should shift to replacing the common toxic fungal strain with novel cultivars that do not produce the mammal-toxic alkaloids but still maintain salt tolerance benefits.

\section{Conclusion}

Apparently, research advances in tall fescue salt-stress signaling and the subsequent molecular and metabolic processes will be critical for the analysis of salt tolerance. However, currently, the improvement of tall fescue performance under salinity is still impaired by complexities in the genomic and integral physiological traits. The recent research advances in -omics technologies should be incorporated into the currently available information. In addition, a recent breakthrough in association mapping techniques in tall fescue using molecular markers will enable the production and analysis of a large number of mutant tall fescue plants which will allow botanists to identify many alleles that are involved in salt tolerance. Collectively, the incorporation of all research breakthroughs and other advancements through collaborative approaches is expected to redesign tall fescue for the future world. Figure 2 shows our proposed mechanism of salt tolerance in tall fescue.

\section{Literature Cited}

Achevaleta, M., C.W. Bacon, C.S. Hoveland, and D.E. Radcliffe. 1989. Effect of the tall fescue endophyte on plant response to environmental stress. Agron. J. 81:83-90.

Allakhverdiev, S.I., A. Sakamoto, Y. Nishiyama, M. Inaba, and N. Murata. 2000. Ionic and osmotic effects of $\mathrm{NaCl}$-induced inactivation of photosystems I and II in Synechococcus sp. Plant Physiol. 123:1047-1056.

Alscher, R.G. and J.L. Hess. 1993. Antioxidants in higher plants. CRC Press, Boca Raton, FL.

Alshammary, S.F., Y.L. Qian, and S.J. Wallner. 2004. Growth response of four turfgrass species to salinity. Agr. Water Mgt. 66:97-111.

Alves, A.G. and T.L. Setter. 2004. Abscisic acid accumulation and osmotic adjustment in cassava under water deficit. Environ. Expt. Bot. 51:259-279.

Apel, K. and H. Hirt. 2004. Reactive oxygen species: Metabolism, oxidative stress, and signal transduction. Annu. Rev. Plant Biol. 55:373-399.

Balmer, D., V. Flors, G. Glauser, and B. Mauch-Mani. 2013. Metabolomics of cereals under biotic stress: Current knowledge and techniques. Front. Plant Sci. 4:82.

Barnett, N.M. and A.W. Naylor. 1966. Amino acid and protein metabolism in bermudagrass during water stress. Plant Physiol. 41:1222-1230.

Batelli, G., P.E. Verslues, F. Agius, Q.S. Qiu, H. Fujii, S. Pan, K.S. Schumaker, S. Grillo, and J.K. Zhu. 2007. sos 2 promotes salt tolerance in part by interacting with the vacuolar H+-ATPase and upregulating its transport activity. Mol. Cell. Biol. 27:7781-7790.

Beard, J.B. 1989. Turfgrass water stress, p. 23-28. In: H. Takatoh (ed.). Drought resistance components, physiological mechanisms, and species-genotype diversity. Proc. 6th Intl. Turfgrass Res. Conf., Tokyo, Japan.

Bennett, O.L. and B.D. Doss. 1960. Effect of soil moisture level on root distribution of cool-season forage species. Agron. J. 52:202207.

Bernstein, L. 1961. Osmotic adjustment of plants to saline media: I. Steady state. Amer. J. Bot. 48:909-918.

Bernstein, L. 1963. Osmotic adjustment of plants to saline media. II. Dynamic phase. Amer. J. Bot. 50:360-370.

Beyrouty, C.A., C.P. West, and E.E. Gbur. 1990. Root development of bermudagrass and tall fescue as affected by cutting interval and growth regulators. Plant Soil 127:23-30.

Bi, A., J. Fan, Z. Hu, G. Wang, E. Amombo, J. Fu, and T. Hu. 2016. Differential acclimation of enzymatic antioxidant metabolism and photosystem II photochemistry in tall fescue under drought and heat and the combined stresses. Front. Plant Sci. 7:453.

Blanco, F.A., M.E. Zanetti, C.A. Casalongue, and G.R. Daleo. 2006. Molecular characterization of a potato MAP kinase transcriptionally regulated by multiple environmental stresses. Plant Physiol. Biochem. 44:315-322.

Blumwald, E. 1987. Tonoplast vesicles for the study of ion transport in plant vacuoles. Physiol. Plant. 69:731-734.

Bonos, S.A., D. Rush, K. Hignight, and W.A. Meyer. 2004. Selection for deep root production in tall fescue and perennial ryegrass. Crop Sci. 44:1770-1775.

Boudsocq, M., M.R. Willmann, M. Mccormack, H. Lee, L. Shan, P. He, J. Bush, S. Cheng, and J. Sheen. 2010. Differential innate immune signaling via $\mathrm{Ca}^{2+}$ sensor protein kinases. Nature 464:418422 
Bowman, D.C., G.R. Cramer, and D.A. Devitt. 2006. Effect of salinity and nitrogen status on nitrogen uptake by tall fescue turf. J. Plant Nutr. 29:1481-1490.

Bray, E.A. 1997. Plant responses to water deficit. Trends Plant Sci. $2: 48-54$

Bush, L.P., H.H. Wilkinson, and C.L. Schardl. 1997. Bioprotective alkaloids of grass-fungal endophyte symbioses. Plant Physiol. 114:1-7. Cabot, C., J.V. Sibole, J. Barcelo, and C. Poschenrieder. 2009. Sodiumcalcium interactions with growth, water, and photosynthetic parameters in salt-treated beans. J. Plant Nutr. Soil Sci. 172:637-643.

Carrow, R.N. 1996. Drought avoidance characteristics of diverse tall fescue cultivars. Crop Sci. 36:371-377.

Castrillo, M. 1992. Sucrose metabolism in bean plants under water deficit. J. Expt. Bot. 43:1557-1561.

Cheeseman, J.M. 1988. Mechanisms of salinity tolerance in plants. Plant Physiol. 87:547-550.

Chidananda, K.H., S. Takahashi, M.E. Quadro, S. Maffei, C. Bossi, S. Bertea, A. Zebelo, N. Muroi, H. Ishihama, W. Yoshioka, J. Boland, Y. Takabayashi, T. Endo, and G. Arimura. 2010. Regulation of arabidopsis defense responses against Spodoptera littoralis by CPKmediated calcium signaling. BMC Plant Biol. 10:97.

Christensen, M.J. and C.R. Voisey. 2009. Tall fescue-endophyte symbiosis, p. 251-272. In: H.A. Fribourg, D.B. Hannaway, and C.P. West (eds.). Tall fescue for the twenty-first century. Agron. Monogr. Vol. 53. Amer. Soc. Agron, Crop Sci. Soc. Amer., Soil Sci. Soc. Amer., Madison, WI.

Clay, K. and C. Schardl. 2002. Evolutionary origins and ecological consequences of endophyte symbiosis with grasses. Amer. Nat. 160:99-127.

Cramer, G.R., E. Epstein, and A. Lauchli. 1989. Na-Ca interactions in barley seedlings: Relationship to ion transport and growth. Plant Cell Environ. 12:551-558.

Cutler, S.R., P.L. Rodriguez, R.R. Finkelstein, and S.R. Abrams. 2010. Abscisic acid: Emergence of a core signaling network. Annu. Rev. Plant Biol. 61:651-679.

Dean, D.E., D.A. Devitt, L.S. Verchick, and R.L. Morris. 1996. Turfgrass quality, growth, and water use influenced by salinity and water stress. Agron. J. 88:844-849.

Debattista, J.P., C.W. Bacon, R. Severson, R.D. Plattner, and J.H. Bouton. 1990. Indole acetic acid production by the fungal endophyte of tall fescue. Agron. J. 82:878-880.

DeWald, D.B., J. Torabinejad, C.A. Jone, J.C. Shope, A.R. Cangelosi, J.E. Thompson, G.D. Prestwich, and H. Hama. 2001. Rapid accumulation of phosphatidyl-inositol 4,5-bisphosphate and inositol 1,4,5-trisphosphate correlates with calcium mobilization in saltstressed arabidopsis. Plant Physiol. 126:759-769.

Dinneny, J.R., T.A. Dinneny, J.Y. Long, J.W. Wang, D. Jung, S. Mace, C. Pointer, S.M. Barron, J. Brady, and P.N. Schiefelbein. 2008. Cell identity mediates the response of arabidopsis roots to abiotic stress. Sci. Signal. 320:942-945.

Dodd, A.N., J. Kudla, and D. Sanders. 2010. The language of calcium signaling. Annu. Rev. Plant Biol. 61:593-620.

Du, H.M., Z.L. Wang, and B.R. Huang. 2009. Differential responses of warm-season and cool-season turfgrass species to heat stress associated with antioxidant enzyme activity. J. Amer. Soc. Hort. Sci. 134:417-422.

Dubiella, U., H. Seybold, G. Durian, E. Komander, R. Lassig, and C.P. Witte. 2013. Calcium-dependent protein kinase/NADPH oxidase activation circuit is required for rapid defense signal propagation. Proc. Natl. Acad. Sci. USA 110:8744-8749.

Dubouzet, J.G., Y. Sakuma, Y. Ito, M. Kasuga, E.G. Dubouzet, S. Miura, M. Seki, K. Shinozaki, and K. Yamaguchi-Shinozaki. 2003. OsDREB genes in rice, Oryza sativa L., encode transcription activators that function in drought, high-salt-, and cold-responsive gene expression. Plant J. 33:751-763.

El-Hamdaoui, A., M. Redondo-Nieto, B. Torralba, R. Rivilla, I. Bonilla, and L. Bolanos. 2003. Influence of boron and calcium on the tolerance to salinity of nitrogen-fixing pea plants. Plant Soil 251:93-103.
Elmi, A.A. and C.P. West. 1995. Endophyte infection effects on stomatal conductance, osmotic adjustment and drought recovery of tall fescue. New Phytol. 131:61-67.

Fu, J., J. Fry, and B. Huang. 2004. Minimum water requirements of four turfgrasses in the transition zone. HortScience 39:1740-1744.

Fu, J., J.D. Fry, and B. Huang. 2007. Growth and carbon metabolism of tall fescue and zoysiagrass as affected by deficit irrigation. HortScience 42:378-381.

Fu, J., B. Huang, and J. Fry. 2010. Osmotic potential, sucrose level, and activity of sucrose metabolic enzymes in tall fescue in response to deficit irrigation. J. Amer. Soc. Hort. Sci. 135:506-510.

Gao, Y. and D. Li. 2014. Growth responses of tall fescue (Festuca arundinacea Schreb.) to salinity stress. Eur. J. Hort. Sci. 79:123-128.

Gao, Y., D. Li, and Y. Chen. 2012. Differentiation of carbonate, chloride, and sulfate salinity responses in tall fescue. Sci. Hort. 139:1-7.

Gorham, J., R.G. Wyn Jones, and A. Bristol. 1990. Partial characterization of the trait for fenhanced $\mathrm{K}^{+}-\mathrm{Na}^{+}$discrimination in the d-genome of wheat. Planta 180:590-597.

Guo, J., L.R. Mcculley, and D.H. Mcnear. 2015. Tall fescue cultivar and fungal endophyte combinations influence plant growth and root exudate composition. Front. Plant Sci. 6:183.

Gupta, B. and B. Huang. 2014. Mechanism of salinity tolerance in plants: Physiological, biochemical, and molecular characterization. Intl. J. Genomics 2014:701596.

Hare, P.D. and W.A. Cress. 1997. Metabolic implications of stressinduced proline accumulation in plants. Plant Growth Regulat. 21:79-102.

Harper, J.F., G. Breton, and A. Harmon. 2004. Decoding $\mathrm{Ca}^{2+}$ signals through plant protein kinases. Annu. Rev. Plant Biol. 55:263-288.

Hasegawa, P.M., R.A. Bressan, J.K. Zhu, and H.J. Bohnert. 2000. Plant cellular and molecular responses to high salinity. Annu. Rev. Plant Physiol. Plant Mol. Biol. 51:463-499.

Hays, K.L., J.F. Barber, M.P. Kenna, and T.G. McCollum. 1991. Drought avoidance mechanisms of selected bermudagrass genotypes. HortScience 26:180-182.

Hirayama, T. and K. Shinozaki. 2010. Research on plant abiotic stress responses in the post-genome era: Past, present, and future. Plant J. 61:1041-1052.

Hosseini, F., M.F. Mosaddeghi, M.A. Hajabbasi, and M.R. Sabzalian. 2015. Aboveground fungal endophyte infection in tall fescue alters rhizosphere chemical, biological, and hydraulic properties in texturedependent ways. Plant Soil 388:351-366.

$\mathrm{Hu}, \mathrm{T}$., K. Chen, L. Hu, E. Amombo, and J. Fu. 2016a. $\mathrm{H}_{2} \mathrm{O}_{2}$ and $\mathrm{Ca}^{2+}{ }_{-}$ based signaling and associated ion accumulation, antioxidant systems, and secondary metabolism orchestrate the response to $\mathrm{NaCl}$ stress in perennial ryegrass. Sci. Rpt. 6:36396.

$\mathrm{Hu}, \mathrm{T}$., H. Li, X. Zhang, H. Luo, and J. Fu. 2011. Toxic effect of $\mathrm{NaCl}$ on ion metabolism, antioxidative enzymes and gene expression of perennial ryegrass. Ecotoxicol. Environ. Saf. 74:20502056.

$\mathrm{Hu}$, T., S. Liu, E. Amombo, and J. Fu. 2015a. Stress memory induced rearrangements of HSP transcription, photosystem II photochemistry and metabolism of tall fescue (Festuca arundinacea Schreb.) in response to high-temperature stress. Front. Plant Sci. 6:403.

Hu, Z., Y. Xie, G. Jin, J. Fu, and H. Li. 2015b. Growth responses of two tall fescue cultivars to $\mathrm{Pb}$ stress and their metal accumulation characteristics. Ecotoxicology 24:563-572.

Hu, L., Z. Zhang, Z. Xiang, and Z. Yang. 2016b. Exogenous application of citric acid ameliorates the adverse effect of heat stress in tall fescue (Lolium arundinaceum). Front. Plant Sci. 7:179.

Huang, B.R. 2001. Drought and heat stress injury to two cool season turfgrasses in relation to antioxidant metabolism and lipid peroxidation. Crop Sci. 41:436-442.

Huang, B. and J.D. Fry. 1998. Root anatomical, morphological, and physiological responses to drought stress for tall fescue cultivars. Crop Sci. 38:1017-1022. 
Ichimura, K., T. Mizoguchi, R. Yoshida, T. Yuasa, and K. Shinozaki. 2000. Various abiotic stresses rapidly activate arabidopsis MAP kinases ATMPK4 and ATMPK6. Plant J. 24:655-665.

Ito, Y., K. Katsura, K. Maruyama, T. Taji, M. Kobayashi, K. Shinozaki, and K. Yamaguchi-Shinozaki. 2006. Functional analysis of rice DREB1/CBF-type transcription factors involved in coldresponsive gene expression in transgenic rice. Plant Cell Physiol. 47:141-153.

Ji, H., J.M. Pardo, B. Giorgia, M.J. Van Oosten, R.A. Bressan, and X. Li. 2013. The salt overly sensitive (SOS) pathway: Established and emerging roles. Mol. Plant Adv. 6:2275-2286.

Jin, S.H., X.Q. Li, and X.L. Jia. 2011. Genotypic differences in the responses of gas exchange, chlorophyll fluorescence, and antioxidant enzymes to aluminum stress in Festuca arundinacea. Russ. J. Plant Physiol. 58:560 (abstr.).

Jonak, C., S. Kiegerl, W. Ligterink, P.J. Barker, N.S. Huskisson, and H. Hirt. 1996. Stress signaling in plants: A mitogen-activated protein kinase pathway is activated by cold and drought. Proc. Natl. Acad. Sci. USA 93:11274-11279.

Kanchiswamy, C.N., H. Takahashi, S. Quadro, M.E. Maffei, S. Bossi, C. Bertea, S. Atsbaha, A. Muroi, N. Ishihama, H. Yoshioka, W. Boland, J. Takabayashi, Y. Endo, T. Sawasaki, and G. Arimura. 2010. Regulation of arabidopsis defense responses against Spodoptera littoralis by cpkmediated calcium signaling. BMC Plant Biol. 10:97.

Kazuo, S. and K. Yamaguchi-Shinozaki. 2007. Gene networks involved in drought stress response and tolerance. J. Expt. Bot. 58:221-227.

Kiegerl, S., F. Cardinale, C. Siligan, A. Gross, E. Baudouin, A. Liwosz, S. Eklöf, S. Till, L. Bögre, H. Hirt, and I. Meskiene. 2000. SIMKK, a mitogen-activated protein kinase (MAPK) kinase, is a specific activator of the salt stress-induced MAPK, SIMK. Plant Cell 12:2247-2258.

Kinraide, T.B. 1999. Interactions among $\mathrm{Ca}^{2+}, \mathrm{Na}^{+}$, and $\mathrm{K}^{+}$in saline toxicity: Quantitative resolution of multiple toxic and ameliorative effects. J. Expt. Bot. 50:1495-1505.

Kirkham, M.B., W.R. Gardner, and G.C. Gerloff. 1969. Leaf water potential of differentially salinized plants. Plant Physiol. 44:1378-1382. Kiyosue, T., Y. Yoshiba, K. Yamaguchi-Shinozaki, and K. Shinozaki. 1996. A nuclear gene encoding mitochondrial proline dehydrogenase, an enzyme involved in proline metabolism, is upregulated by proline but downregulated by dehydration in arabidopsis. Plant Cell 8:1323-1335.

Knight, H. 2000. Calcium signaling during abiotic stress in plants. Intl. Rev. Cytol. 195:269-324.

Kong, X., J. Pan, M. Zhang, X. Xing, Y. Zhou, Y. Liu, and D. Li. 2011. ZmMKK4, a novel group $\mathrm{C}$ mitogen-activated protein kinase in maize (Zea mays), confers salt and cold tolerance in transgenic arabidopsis. Plant Cell Environ. 34:1291-1303.

Kravchik, M. and N. Bernstein. 2013. Effects of salinity on the transcriptome of growing maize leaf cells point at cell-age specificity in the involvement of the antioxidative response in cell growth restriction. BMC Genomics 14:24.

Lahaya, P.A. and E. Epstein. 1969. Salt toleration by plants: Enhancement with calcium. Science 166:395-396.

Lee, S.H., N. Ahsan, K.W. Lee, D.H. Kim, D. Lee, D.G. Lee, S.S. Kwak, S.Y. Kwon, T.H. Kim, and B.H. Lee. 2007. Simultaneous overexpression of both $\mathrm{CuZn}$ superoxide dismutase and ascorbate peroxidase in transgenic tall fescue plants confers increased tolerance to a wide range of abiotic stresses. J. Plant Physiol. 164:16261638 .

Leuchtmann, A., D. Schmidt, and L.P. Bush. 2000. Different levels of protective alkaloids in grasses with stroma-forming and seed transmitted Epichloe/Neotyphodium endophytes. J. Chem. Ecol. 26:10251036.

Li, H., T. Hu, E. Amombo, and J. Fu. 2017. Transcriptome profilings of two tall fescue (Festuca arundinacea) cultivars in response to lead $(\mathrm{Pb})$ stress. BMC Genomics 18:145.

Lou, Y., P. Zhao, D. Wang, E. Amombo, X. Sun, H. Wang, and Y. Zhuge. 2017. Germination, physiological responses and gene expression of tall fescue (Festuca arundinacea Schreb.) growing under $\mathrm{Pb}$ and $\mathrm{Cd}$. PLoS One 12:e0169495.

Lunt, O.T., B.B. Younger, and J.J. Oertli. 1961. Salinity tolerance of five turfgrass cultivars. Agron. J. 53:247-249.

Lynch, J., V.S. Polito, and A. Lauchli. 1989. Salinity stress increases cytoplasmic $\mathrm{Ca}^{2+}$ activity in maize root protoplasts. Plant Physiol. 90:1271-1274.

Lzwiy, I.A. and P.C. Morris. 2007. A mutation in the arabidopsis MAP kinase gene results in enhanced seedling stress tolerance. Plant Sci. 173:302-308.

Ma, D.M., W.R. Xu, H.W. Li, F.X. Jin, L.N. Guo, J. Wang, H.J. Da, and X. Xu. 2014. Co-expression of the Arabidopsis SOS genes enhances salt tolerance in transgenic tall fescue (Festuca arundinacea Schreb.). Protoplasma 251:219-231.

Maeda, Y. and R. Nakazawa. 2008. Effects of the timing of calcium application on the alleviation of salt stress in the maize, tall fescue, and reed canarygrass seedlings. Biol. Plant. 52:153-156.

Mahajan, S., K. Girdhar, and N. Tuteja. 2008. Calcium and salt-stress signaling in plants: Shedding light on SOS pathway. Arch. Biochem. Biophys. 471:146-158.

Man, D., Y.X. Bao, L.B. Han, and X. Zhang. 2011. Drought tolerance associated with proline and hormone metabolism in two tall fescue cultivars. HortScience 46:1027-1032.

Marcum, K.B., M.C. Engelke, S.J. Morton, and R.H. White. 1995. Rooting characteristics and associated drought resistance of zoysiagrass. Agron. J. 87:534-538.

Martin, R.C., K. Glover-Cutter, J.C. Baldwin, and J.E. Dombrowski. 2012. Identification and characterization of a salt stress-inducible zinc finger protein from Festuca arundinacea. BMC Res. Notes 5:66. Mian, M.R., Y. Zhang, Z. Wang, J.Y. Zhang, X. Cheng, L. Chen, K. Chekhovskiy, X. Dai, C. Mao, F. Cheung, X. Zhao, J. He, A.D. Scott, C.D. Town, and G.D. May. 2008. Analysis of tall fescue ESTs representing different abiotic stresses, tissue types and developmental stages. BMC Plant Biol. 8:27.

Morvan-Bertrand, A., J. Boucaud, J. Le Saos, and M.P. Prud'homme. 2001. Roles of the fructans from leaf sheaths and from the elongating leaf bases in the regrowth following defoliation of Lolium perenne L. Planta 213:109-120.

Munns, R. 1988. Effect of high external $\mathrm{NaCl}$ concentrations on ion transport within the shoot of Lupinus albus ions in xylem sap. Plant Cell Environ. 11:283-289.

Munns, R. 1993. Physiological processes limiting plant growth in saline soil: Some dogmas and hypotheses. Plant Cell Environ. 16:1524.

Munns, R. 2002. Comparative physiology of salt and water stress. Plant Cell Environ. 25:239-250.

Munns, R. 2011. Plant adaptations to salt and water stress: Differences and commonalities. Adv. Bot. Res. 57:1-32.

Munns, R. and M. Tester. 2008. Mechanisms of salinity tolerance. Annu. Rev. Plant Biol. 59:651-681.

Nagabhyru, P., R.D. Dinkins, C.L. Wood, C.W. Bacon, and C.L. Schardl. 2013. Tall fescue endophyte effects on tolerance to waterdeficit stress. BMC Plant Biol. 13:127.

Newman, P.R. and L.E. Moser. 1988. Seedling root development and morphology of cool-season and warm-season forage grasses. Crop Sci. 28:148-151.

Nordstrom, A., F.A. Jacobs, and L. Eliasson. 1991. Effect of exogenous indole-3-acetic acid and indole-3-butyric acid on internal levels of the respective auxins and their conjugation with aspartic acid during adventitious root formation in pea cuttings. Plant Physiol. 96:856-861.

Oh, S.J., S.I. Song, Y.S. Kim, H.J. Jang, S.Y. Kim, M. Kim, Y.K. Kim, B.H. Nahm, and J.K. Kim. 2005. Arabidopsis CBF3/DREB1A and $\mathrm{ABF} 3$ in transgenic rice increased tolerance to abiotic stress without stunting growth. Plant Physiol. 138:341-351.

Pavis, N., J. Boucaud, and M.P. Prud'homme. 2001. Fructans and fructan-metabolizing enzymes in leaves of Lolium perenne. New Phytol. 150:97-109. 
Pei, Z.M. 2000. Calcium channels activated by hydrogen peroxide mediate abscisic acid signaling in guard cells. Nature 406:731734.

Pellegrineschi, A., M. Reynolds, M. Pacheco, R.M. Brito, R. Almeraya, K. Yamaguchi-Shinozaki, and D. Hoisington. 2004. Stress-induced expression in wheat of the Arabidopsis thaliana DREB1A gene delays water stress symptoms under greenhouse conditions. Genome 47:493-500.

Premachandra, G.S., H. Aneoka, H. Fujita, and S. Ogata. 1992. Leaf water relations, osmotic adjustment, cell membrane stability, epicuticular wax load and growth as affected by increasing water deficit in sorghum. J. Expt. Bot. 43:1569-1576.

Raghavendra, A.S., V.K. Gonugunta, A. Christmann, and E. Grill. 2010. ABA perception and signaling. Trends Plant Sci. 15:395-401. Rasmussen, S., A.J. Parsons, A. Popay, H. Xue, and A. Newman. 2008. Plant-endophyte-herbivore interactions: More than just alkaloids? Plant Signal. Behav. 3:974-977.

Rekika, D., M.M. Nachit, J.L. Araus, and P. Monneveus. 1998. Effects of water deficit on photosynthetic rate and osmotic adjustment in tetraploid wheat. Photosynthetica 35:129-138.

Rhodes, D., S. Handa, and R.A. Bressan. 1986. Metabolic changes associated with adaptation of plant cells to water stress. Plant Physiol. 82:890-903.

Richards, L.A. (ed.). 1954. Diagnosis and improvement of saline and alkali soils. Agr. Hdbk. No. 60. U.S. Dept. Agr., Washington, DC.

Sanders, D., J. Pelloux, C. Brownlee, and J.F. Harper. 2002. Calcium at the crossroads of signaling. Plant Cell 14:401-417.

Schachtman, D.P., S.D. Tyerman, and B.R. Terry. 1991. The $\mathrm{K}^{+} / \mathrm{Na}^{+}$ selectivity of a cation channel in the plasma membrane of root cells does not differ in salt-tolerant and salt-sensitive wheat species. Plant Physiol. 97:598-605.

Schnyder, H. and C.J. Nelson. 1987. Growth rates and carbohydrate fluxes within the elongation zone of tall fescue leaf blades. Plant Physiol. 85:548-553.

Sheen, J. 1996. $\mathrm{Ca}^{2+}$-dependent protein kinases and stress signal transduction in plants. Science 274:1900-1902.

Shi, H., M. Ishitani, C. Kim, and J.K. Zhu. 2000. The Arabidopsis thaliana salt tolerance gene SOS1 encodes a putative $\mathrm{Na}^{+} / \mathrm{H}^{+}$ antiporter. Proc. Natl. Acad. Sci. USA 97:6896-6901.

Shou, H., P. Bordallo, and K. Wang. 2004. Expression of the Nicotiana protein kinase (NPK1) enhanced drought tolerance in transgenic maize. J. Expt. Bot. 55:1013-1019.

Sotiropoulos, T.E. 2007. Effect of $\mathrm{NaCl}$ and $\mathrm{CaCl}_{2}$ on growth and contents of minerals, chlorophyll, proline, and sugars in the apple rootstock M4 cultured in vitro. Biol. Plant. 51:177-180.

Spollen, W.G. and C.J. Nelson. 1994. Response of fructan to water deficit in growing leaves of tall fescue. Plant Physiol. 106:329336.

Srivastava, A., A. Rai, V. Patade, and P. Suprasanna. 2013. Calcium signaling and its significance in alleviating salt stress in plants, p. 197-218. In: P. Ahmad, M.M. Azooz, and M.N.V. Prasad (eds.). Salt stress in plants: Signaling, omics, and adaptations. Springer, New York, NY.

Stewart, G.R. and J.A. Lee. 1974. The role of proline accumulation in halophytes. Planta 120:279-289.

Szabados, L. and A. Savoure. 2010. Proline: A multifunctional amino acid. Trends Plant Sci. 15:89-97.

Takahashi, S., T. Katagiri, T. Hirayama, and K. Yamaguchi-Shinozaki. 2001. Hyperosmotic stress induces a rapid and transient increase in inositol 1,4,5-trisphosphate independent of abscisic acid in arabidopsis cell culture. Plant Cell Physiol. 42:214-222.

Talukder, S.K., P. Azhaguvel, S. Mukherjee, C.A. Young, Y. Tang, N. Krom, and M.C. Saha. 2015. De novo assembly and characterization of tall fescue [Lolium arundinaceum (Schreb.) Darbysh.] transcriptome under water stress. Plant Genome 8.

Taylor, H.M. 1983. A program to increase plant available water through rooting modification, p. 463-472. In: W. Bohm (ed.). Root ecology and its practical application: A contribution to the investigation of the whole plant. Verlag Gumpenstein, Irdning, Austria.

Thimann, K. 1987. Plant senescence: A proposed integration of the constituent processes, p. 1-19. In: W.W. Thomson, E.A. Nothangel, and R.C. Huffaker (eds.). Plant senescence: Its biochemistry and physiology. Amer. Soc. Plant Physiologists, Rockville, MD.

Torello, W.A. and A.G. Symington. 1984. Screening of turfgrass species and cultivars for $\mathrm{NaCl}$ tolerance. Plant Soil 82:155-161.

Umezawa, T., K. Nakashima, T. Miyakawa, T. Kuromori, M. Tanokura, K. Shinozaki, and K. Yamaguchi-Shinozaki. 2010. Molecular basis of the core regulatory network in abscisic acid responses: Sensing, signaling, and transport. Plant Cell Physiol. 51:1821-1839.

Vassey, T.L., P. Quick, T.D. Sharkey, and M. Stitt. 1991. Water stress, carbon dioxide, and light effect on sucrose phosphate synthase activity in Phaseolus vulgaris. Physiol. Plant. 81:37-44.

Vendruscolo, E.C.G., I. Schuster, M. Pileggi, C.A. Scapim, H.B.C. Molinari, C.J. Marur, and L.G. Vieira. 2007. Stress-induced synthesis of proline confers tolerance to water deficit in transgenic wheat. J. Plant Physiol. 164:1367-1376.

Verbruggen, N. and C. Hermans. 2008. Proline accumulation in plants: A review. Amino Acids 35:753-759.

Verslues, P.E. 2007. Interaction of SOS2 with nucleoside diphosphate kinase 2 and catalases reveals a point of connection between salt stress and $\mathrm{H}_{2} \mathrm{O}_{2}$ signaling in Arabidopsis thaliana. Mol. Cell. Biol. 27:7771-7780.

Voetberg, G.S. and R.E. Sharp. 1991. Growth of the maize primary root tip at low water potentials: Role of increased proline deposition in osmotic adjustment. Plant Physiol. 96:1125-1130.

Watkins, E., S. Fei, D. Gardner, J. Stier, S. Bughrara, D. Li, C. Bigelow, L. Schleicher, B. Horgan, and K. Diesburg. 2011. Lowinput turfgrass species for the north central United States. Appl. Turfgrass Sci. 8.

Weaver, J.E. and E. Zink. 1955. Length of life of roots of ten species of perennial range and pasture grasses. Plant Physiol. 45:201-217.

West, C.P., D.M. Oosterhuis, and S.D. Wullschleger. 1990. Osmotic adjustment in tissues of tall fescue in response to water deficit. Environ. Expt. Bot. 30:149-156.

Xiong, L., Z. Gong, C.D. Rock, S. Subramanian, Y. Guo, W. Xu, D. Galbraith, and J. Zhu. 2001. Modulation of abscisic acid signal transduction and biosynthesis by an Sm-like protein in arabidopsis. Dev. Cell 1:771-781.

Xiong, L. and Y. Yang. 2003. Disease resistance and abiotic stress tolerance in rice are inversely modulated by an abscisic acidinducible mitogen-activated protein kinase. Plant Cell 15:745759.

Xiong, L. and J. Zhu. 2003. Regulation of abscisic acid biosynthesis. Plant Physiol. 133:29-36.

Xu, Y.F., X.T. Chu, J.J. Fu, L.Y. Yang, and T.M. Hu. 2016. Crosstalk of nitric oxide with calcium-induced tolerance of tall fescue leaves to high irradiance. Biol. Plant. 60:376-384.

Yamaguchi-Shinozaki, K. and K. Shinozaki. 2005. Organization of cis-acting regulatory elements in osmotic- and cold-stress-responsive promoters. Trends Plant Sci. 10:88-94.

Yang, Q., Z.Z. Chen, X.F. Zhou, H.B. Yin, X. Li, X.F. Xin, H.H. Xu, J.K. Zhu, and Z. Gong. 2009. Overexpression of sos (salt overly sensitive) genes increases salt tolerance in transgenic arabidopsis. Mol. Plant 2:22-31.

Yin, L., M. Ren, M. Wei, L. Wu, Y. Zhou, X. Li, and Y. Gao. 2014. Neotyphodium coenophialum-infected tall fescue and its potential application in the phytoremediation of saline soils. Intl. J. Phytoremediation 16:235-246.

Youngner, V.B., A.W. Marsh, R.A. Strohman, V.A. Gibeault, and S. Spalding. 1981. Water use and quality of warm season and cool season turfgrasses, p. 257-259. In R.W. Sheard (ed.). Proc. 4th Intl. Turfgrass Res. Conf., Intl. Turfgrass Soc./Univ. Guelph, Guelph, ON, Canada. 
Yue, Y., M. Zhang, J. Zhang, L. Duan, and Z. Li. 2012. sos1 gene overexpression increased salt tolerance in transgenic tobacco by maintaining a higher $\mathrm{K}^{+} / \mathrm{Na}^{+}$ratio. J. Plant Physiol. 169:255261.

Zhang, X., E.H. Ervin, G.K. Evanylo, and K.C. Haering. 2009. Impact of biosolids on hormone metabolism in drought-stressed tall fescue. Crop Sci. 49:1893-1901.

Zhang, X., E.H. Ervin, G. Evanylo, C. Sherony, and C. Peot. 2005. Biosolids impact on tall fescue drought resistance. J. Residuals Sci. Technol. 2:173-180.

Zhang, C. and M.T. McManus. 2000. Identification and characterization of two distinct acid phosphatases in cell walls of roots of white clover. Plant Physiol. Biochem. 38:259-270.
Zhang, X. and R.E. Schmidt. 2000. Hormone containing products' impact on antioxidant status of tall fescue and creeping bentgrass subjected to drought. Crop Sci. 40:1344-1349.

Zhang, L., D. Xi, S. Li, Z. Gao, S. Zhao, J. Shi, C. Wu, and X. Guo. 2011. A cotton group C MAP kinase gene, GhMPK2, positively regulates salt and drought tolerance in tobacco. Plant Mol. Biol. $77: 17-31$.

Zhao, J.S., D.Y. Zhi, Z.Y. Xue, H. Liu, and G.M. Xia. 2007. Enhanced salt tolerance of transgenic progeny of tall fescue (Festuca arundinacea) expressing a vacuolar $\mathrm{Na}^{+} / \mathrm{H}^{+}$antiporter gene from Arabidopsis. J. Plant Physiol. 164:1377-1383.

Zhu, J.K. 2002. Drought and salt stress signal transduction in plants. Annu. Rev. Plant Biol. 53:247-273. 